\title{
BEBAN KERJA TENAGA KERJA TUKANG BESI DI JAKARTA
}

\author{
Ryan Hartono' dan Basuki Anondho \\ ${ }^{1}$ Program Studi Sarjana Teknik Sipil, Universitas Tarumanagara, Jl.Letjen S. Parman No.1 Jakarta \\ Email: ryanhartono66@gmail.com \\ ${ }^{2}$ Program Studi Sarjana Teknik Sipil, Universitas Tarumanagara, Jl.Letjen S. Parman No.1 Jakarta \\ Email: basukia@ft.untar.ac.id
}

\begin{abstract}
ABSTRAK
Pekerjaan konstruksi adalah pekerjaan yang berat secara fisik. Pekerjaan yang menuntut fisik menyebabkan kelelahan fisik yang dikaitkan dengan penurunan produktivitas. Oleh karena itu, diperlukan perhitungan beban kerja terhadap tenaga kerja konstruksi Pengukuran fisiologis dari data pengeluaran energi dikumpulkan dari 51 tukang besi yang melakukan beberapa pekerjaan konstruksi. Pengukuran pengeluaran energi selama kegiatan konstruksi dianggap sebagai tolak ukur yang baik dari beban kerja fisiologis yang dialami oleh pekerja konstruksi. Data yang diukur dievaluasi terhadap pedoman yang diterbitkan untuk tingkat kinerja fisik yang dapat diterima. Seluruh hasil perhitungan didasarkan pada data hasil kuesioner yang telah diisi dengan mengkonversikannya dengan nilai pengeluaran energi pada penelitian terdahulu. Hasil dari penelitian ini menunjukan bahwa beban kerja yang dimiliki tukang besi termasuk dalam kategori sangat berat. Hal ini menunjukan perlunya menerapkan konsep fisiologi kerja di tempat kerja untuk kesehatan dan keselamatan kerja yang lebih baik bagi tenaga kerja konstruksi khususnya di Jakarta.
\end{abstract}

Kata Kunci: Pekerjaan konstruksi, beban kerja, pengeluaran energi

\begin{abstract}
Construction craft work is a physically strenuous and demanding occupation. Physically demanding work leads to physical fatigue which is associated with decreased productivity. This paper investigates the feasibility of measuring in situ physical demands. Physiological measures of energy expenditure data were collected for 51 ironwokers performing several construction work. The measurement of energy expenditure during physical work activities is considered a good measure of the physiological workload experienced by construction workers. The collected data were evaluated against published guidelines for acceptable levels of physical performance. The result point to show how much labour's workload based on their perspective related to energy expenditure.The result of this study indicate that the workload of ironworkers classified very heavy. The needs is to apply concepts of work physiology at the workplace to better the occupational health and safety of the construction workforce especially in Jakarta.
\end{abstract}

Keywords: construction work, workload, energy expenditure.

\section{PENDAHULUAN}

\section{Latar belakang}

Kegiatan konstruksi adalah kegiatan yang berkaitan dengan upaya pembangunan infrastruktur, yang mempunyai rangkaian kegiatan dan memenuhi persyaratan melalui suatu ruang lingkup pekerjaan tertentu yang dilakukan beberapa kelompok orang. Salah satu sumber daya (resources) dalam proyek konstruksi adalah Sumber Daya Manusia (SDM). Tenaga Kerja memiliki peran yang sangat penting dalam meningkatkan kinerja konstruksi (Jergeas, 2010; Castaneda et al, 2003; 2005).

Tingkat produktivitas tenaga kerja harus diketahui agar penggunaan sumber daya manusia realistis. produktivitas dipengaruhi oleh 3 faktor yaitu beban kerja, kapasitas kerja dan beban tambahan akibat lingkungan kerja. Beban kerja sendiri berhubungan dengan beban fisik, mental maupun sosial yang mempengaruhi tenaga kerja. Pekerja konstruksi rentan terhadap kelelahan karena pekerjaan konstruksi pada umumnya melibatkan beban kerja yang berat (Hartmann dan Fleischer; 2005). Kelelahan kerja menyebabkan kurangnya produktivitas dan motivasi, ketidakteraturan bekerja, penilaian yang buruk, kualitas pekerjaan yang buruk, ketidakpuasan hasil kerja, kecelakaan dan cedera (Brouha, 1967 dan Janaro, 1982). 
Beberapa studi sebelumnya juga menyebutkan bahwa pekerja yang merasakan kelelahan mengalami kesulitan dengan fungsi fisik dan atau kognitifnya(Zhang et al; 2015). Memahami kebutuhan fisik dari pekerjaan konstruksi sangat penting untuk melindungi keselamatan dan kesehatan sekaligus dapat meningkatkan produktivitas tenaga kerja. Berdasarkan penelitian - penelitian diatas, penelitian ini akan mencoba menghitung beban kerja tenaga kerja konstruksi khususnya tukang besi berdasarkan pengeluaran energinya

\section{Tujuan penelitian}

Berdasarkan latar belakang, tujuan dari penelitian ini adalah Tujuan penelitian ini adalah untuk memperoleh nilai beban kerja (kalori) yang dimiliki oleh seorang tukang besi berdasarkan persepsi tukang yang dikorelasikan dengan nilai pengeluaran energinya.

\section{Tenaga kerja}

Menurut Pokok Ketenagakerjaan No. 14 Tahun 1969 menyatakan bahwa tenaga kerja ialah setiap orang yang dapat melakukan pekerjaan baik di dalam maupun di luar hubungan kerja guna menghasilkan barang atau jasa untuk memenuhi suatu kebutuhan masyarakat. Hal ini akan dibahas khususnya tenaga kerja di proyek konstruksi.

Soeharto (1997) menyatakan bahwa salah satu sumber daya yang menjadi penentu keberhasilan suatu proyek konstruksi adalah tenaga kerja. Pada umumnya proyek konstruksi berlangsung dalam kondisi yang berbeda-beda, Jenis dan intensitas kegiatan proyek berubah sepanjang siklusnya, sehingga penyediaan jumlah tenaga, jenis ketrampilan dan keahliannya harus mengikuti tuntutan perubahan kegiatan yang sedang berlangsung

\section{Fisiologis kerja}

Fisiologi Kerja merupakan salah satu cabang ilmu ergonomi yang fokus terhadap pengukuran energi yang dikeluarkan atau energi yang dikonsumsi oleh manusia dalam menjalankan aktivitasnya. Energi yang dikeluarkan/dikonsumsi terjadi karena adanya proses metabolisme yang terjadi didalam otot yang ditunjang oleh sistem cardiovascular dan sistem pernafasan yang terdapat di dalam tubuh. Fokus utama dari fisiologi kerja adalah mencegah pekerja mengalami kelelahan fisik dengan mengurangi tuntutan pekerjaan (Astrand dan Rodahl, 1986).

Beberapa prinsip fisiologi kerja:

1. Mengukur permintaan fisiologi

2. Mengukur pengeluaran energi

3. Pengukuran penyerapan oksigen

4. Menggunakan pengeluaran energi absolut sebagai kriteria beban kerja

5. Denyut jantung sebagai kriteria beban kerja

\section{Beban kerja}

Beban Kerja adalah beban fisik maupun non fisik yang ditanggung oleh seorang pekerja dalam menyelesaikan pekerjaannya. Santoso (2013) dalam bukunya tentang konsep manajemen sumber daya manusia menjelaskan, konsep analisis beban kerja hadir sebagai suatu teknikal praktis yang dapat dipergunakan untuk mengkuantitatifkan dan menghitung produktifitas karyawan. Hasil dari analisis beban kerja juga dapat dipergunakan sebagai landasan dalam menentukan jumlah sumber daya manusia yang dibutuhkan organisasi secara efektif dan efisien.

\section{Faktor fisiologis yang mempengaruhi beban kerja}

Ada beberapa faktor fisiologis yang mempengaruhi beban kerja seperti berikut;

1. Pengeluaran Energi

2. Denyut nadi

3. Konsumsi oksigen

4. Otot

5. Suhu tubuh

6. Stress

7. Emosi

8. Mental

\section{METODOLOGI PENELITIAN}

\section{Penyusunan kuesioner}

Penelitian ini dimulai dari penyusunan kuesioner yang diperoleh dari studi literatur dengan mencari dan mengumpulkan buku, jurnal, serta penelitian terdahulu mengenai faktor fisiologi yang berpengaruh terhadap beban 
kerja tenaga kerja konstruksi. Setelah melakukan tabulasi identifikasi variabel fisiologi, langkah selanjutnya ialah menyusun kuesioner berdasarkan variabel yang telah diperoleh dari variabel fisiologi dengan respondennya adalah tukang besi. Kuesioner dibuat dengan menggunakan skala likert.

\section{Distribusi dan pengumpulan data kuesioner}

Kuesioner ini didistribusikan ke beberapa proyek bangunan gedung bertingkat di Jakarta untuk mengumpulkan data

- data proyek dan juga hasil jawaban kuesioner yang diperlukan untuk mengolah data. Data yang disebar sebanyak 60 kuesioner dan mendapatkan balasan sebanyak 51 responden. Data hasil kuesioner dapat dikelompokkan lagi ke dalam tabel untuk melihat jawaban - jawaban responden terkait pernyataan dari hasil studi literatur. Setelah data kuesioner terkumpul, langkah selanjutnya adalah uji validasi dan reliabilitas. Pada penelitian ini digunakan uji validitas menggunakan rumus Product Moment dari Pearson dan bantuan SPSS ${ }^{\circledR}$, setelah seluruh butir pertanyaan dinyatakan valid dan reliabel baru dapat dilakukan proses analisis data.

\section{Metode Analisis Data}

Proses analisa data dilakukan dengan menghitung nilai RII ( Relative Importance Index ) dari masing - masing variabel pada kuesioner, yaitu berdasarkan beban fisik, kemampuan, tingkat kelelahan, dan pengaruh psikologis. Nilai dari RII dikalkulasikan dengan persamaan:

$$
R I I i=\frac{n 1+2 n 2+3 n 3+4 n 4+5 n 5}{5(n 1+n 2+n 3+n 4+n 5)}
$$

Keterangan :

RIIi

$=$ Nilai RII untuk pertanyaan $\mathrm{i}$

n1,n2,n3,n4,n5 = Jumlah responden yang memberi skor "1" mewakili sangat tidak setuju; "2" mewakili sedikit setuju;"3”mewakili cukup setuju;“4” mewakili setuju;"5" mewakili sangat setuju.

Setelah mendapatkan nilai RII dari masing - masing pertanyaan, akan dilakukan ranking dari nilai RII terbesar hingga yang terkecil untuk nilai RII yang paling besar akan mendapat ranking 1 begitu selanjutnya sampai ranking terendah.

Selanjutnya menentukan beban kerja yang mereka miliki. Untuk menentukan beban kerja yang dimiliki tukang besi didasarkan pada tabel beban kerja berdasarkan pekerjaan konstruksi dimana pada tabel tersebut terdapat beberapa aktifitas pekerjaan konstruksi dengan nilai pengeluaran energinya seperti terlihat di Tabel 1

Tabel 1. Beban Kerja berdasarkan Pekerjaan Konstruksi (Abdelhamid dan Everett, 2002)

\begin{tabular}{|c|c|l|c|}
\hline Tipe Pekerjaan & Nomor Pekerjaan & \multicolumn{1}{|c|}{ Jenis Pekerjaan } & $\begin{array}{c}\text { Pengeluaran Energi } \\
\text { (Kkal/menit) }\end{array}$ \\
\hline Tukang Besi & 71 & Clean-up (gather tools) & 2.61 \\
\cline { 2 - 4 } & 50 & Layout Column footing locations & 3.53 \\
\cline { 2 - 4 } & 33 & Install roof insulation material & 3.53 \\
\cline { 2 - 4 } & 28 & Connect Perlins to steel frame & 3.86 \\
\cline { 2 - 4 } & 29 & Connect perlins to steel frame & 3.96 \\
\cline { 2 - 4 } & 61 & Install tie wire & 4.25 \\
\cline { 2 - 4 } & 73 & Remove form ties & 4.35 \\
\cline { 2 - 4 } & 46 & Install rebar & 4.83 \\
\cline { 2 - 4 } & 27 & Setup crane to hoist perlins & 5.17 \\
\cline { 2 - 4 } & 53 & Install rebar & 5.31 \\
\cline { 2 - 4 } & 74 & Strip and stack formwork panels & 5.31 \\
\cline { 2 - 4 } & 26 & Assemble window (glass) frame & 5.60 \\
\hline 32 & Install foor insulation material & 5.65 \\
\hline
\end{tabular}


Konversi beban kerja dilakukan dengan cara mengalikan nilai RII dari setiap butir pertanyaan dengan nilai pengeluaran energi seperti pada persamaan berikut;

$$
B K n=P n \times E E n
$$

Keterangan :

$\mathrm{BKn}=$ =Nilai Beban kerja untuk pertanyaan $\mathrm{n}(\mathrm{Kkal} / \mathrm{menit})$

EEn =Nilai pengeluaran energi untuk pertanyaan $\mathrm{n}(\mathrm{Kkal} / \mathrm{menit})$

Pn =Nilai RII dari pernyataan $n$

Nilai pengeluaran energi dikorelasikan dengan setiap butir pertanyaan yang ada, setelah mendapatkan nilai beban kerja untuk setiap pertanyaan pada variabel selanjutnya dijumlahkan lalu dibagi dengan jumlah butir pertanyaan setiap variabel dengan persamaan:

$$
B K V A R n=\frac{B K 1+B K 2+\cdots+B K n}{n}
$$

\section{Keterangan :}

$\begin{array}{ll}\mathrm{BKVARn} & =\text { Nilai beban kerja untuk variabel } \mathrm{n}(\mathrm{Kkal} / \mathrm{menit}) \\ \mathrm{BKn} & =\text { Nilai beban kerja untuk pertanyaan } \mathrm{n}(\mathrm{Kkal} / \mathrm{menit}) \\ \mathrm{n} & =\text { Jumlah Butir pertanyaan }\end{array}$

Hasil dari persamaan tersebut akan menunjukan variabel mana yang memiliki beban kerja paling besar berdasarkan persepsi dari tukang besi yang tersebar di beberapa proyek konstruksi di Jakarta.

\section{ANALISIS DAN PEMBAHASAN}

Dalam penelitian ini, terdapat 51 responden yang mengisi kuesioner. Empat variabel pada kuesioner dengan total 21 butir pertanyaan dianalisis dengan metode RII ( Relative Importance Index). Hasil analisis RII variabel beban fisik ditunjukan dalam Tabel 2, variabel Kemampuan ditunjukan dalam Tabel 3, variabel Tingkat Kelelahan ditunjukan dalam Tabel 4, dan variabel Pengaruh Psikologis ditunjukan dalam Tabel 5.

Tabel 2. Hasil Perhitungan Beban Kerja untuk Variabel Beban Fisik Tukang Besi

\begin{tabular}{|c|c|c|c|c|}
\hline $\begin{array}{c}\text { No. } \\
\text { Pertanyaan }\end{array}$ & $\begin{array}{c}\text { RII } \\
(\mathrm{P})\end{array}$ & Ranking & $\begin{array}{c}\text { Pengeluaran } \\
\text { Energi } \\
(\mathrm{EE})(\text { Kkal/menit })\end{array}$ & $\begin{array}{c}\text { Beban Kerja } \\
(\mathrm{BK})\end{array}$ \\
\hline 3 & 0.819608 & 1 & 5.65 & 4.630784 \\
\hline 4 & 0.752941 & 2 & 5.6 & 4.216471 \\
\hline 1 & 0.701961 & 3 & 3.53 & 2.477922 \\
\hline 2 & 0.666667 & 4 & 2.61 & 1.74 \\
\hline \multicolumn{2}{|r}{} & Jumlah & 13.06518 \\
\cline { 3 - 5 } & & Rata-rata & 3.266294 \\
\cline { 3 - 4 } & & &
\end{tabular}


Tabel 3. Hasil Perhitungan Beban Kerja untuk Variabel Kemampuan Tukang Besi

\begin{tabular}{|l|l|l|l|l|}
\hline $\begin{array}{l}\text { No. } \\
\text { Pertanyaan }\end{array}$ & $\begin{array}{l}\text { RII } \\
(\mathrm{P})\end{array}$ & Ranking & $\begin{array}{l}\text { Pengeluaran } \\
\text { Energi } \\
(\text { EE)(Kkal/menit) }\end{array}$ & $\begin{array}{l}\text { Beban Kerja } \\
(\text { BK) }\end{array}$ \\
\hline 1 & 0.815686 & 1 & 5.65 & 4.608627 \\
\hline 2 & 0.803922 & 2 & 5.6 & 4.501961 \\
\hline 5 & 0.764706 & 3 & 5.31 & 4.060588 \\
\hline 4 & 0.717647 & 4 & 3.53 & 2.533294 \\
\hline 3 & 0.694118 & 5 & 3.53 & 2.450235 \\
\hline 6 & 0.662745 & 6 & 2.61 & 1.729765 \\
\hline & & & Jumlah & 19.88447 \\
\cline { 2 - 5 } & & & Rata-rata & 3.314078 \\
\cline { 3 - 5 } & & & &
\end{tabular}

Tabel 4. Hasil Perhitungan Beban Kerja untuk Variabel Tingkat Kelelahan Tukang Besi

\begin{tabular}{|l|l|l|l|l|}
\hline $\begin{array}{l}\text { No. } \\
\text { Pertanyaan }\end{array}$ & $\begin{array}{l}\text { RII } \\
(\mathrm{P})\end{array}$ & Ranking & $\begin{array}{l}\text { Pengeluaran } \\
\text { Energi } \\
(\mathrm{EE})(\text { Kkal/menit })\end{array}$ & $\begin{array}{l}\text { Beban Kerja } \\
(\mathrm{BK})\end{array}$ \\
\hline 2 & 0.941176 & 1 & 5.65 & 5.317647 \\
\hline 4 & 0.843137 & 2 & 5.6 & 4.721569 \\
\hline 1 & 0.784314 & 3 & 5.31 & 4.164706 \\
\hline 3 & 0.745098 & 4 & 5.31 & 3.956471 \\
\hline 5 & 0.67451 & 5 & 3.86 & 2.603608 \\
\hline 6 & 0.67451 & 6 & 3.53 & 2.38102 \\
\hline 7 & 0.662745 & 7 & 3.53 & 2.33949 \\
\hline 8 & 0.619608 & 8 & 2.61 & 1.617176 \\
\hline & & & Jumlah & 27.10169 \\
\cline { 4 - 5 } & & & Rata-rata & 3.387711 \\
\cline { 3 - 5 } & & &
\end{tabular}

Tabel 5. Hasil Perhitungan Beban Kerja untuk Variabel Pengaruh Psikologis Tukang Besi

\begin{tabular}{|l|l|l|l|l|}
\hline $\begin{array}{l}\text { No. } \\
\text { Pertanyaan }\end{array}$ & $\begin{array}{l}\text { RII } \\
(\mathrm{P})\end{array}$ & Ranking & $\begin{array}{l}\text { Pengeluaran } \\
\text { Energi } \\
(\mathrm{EE})(\mathrm{Kkal} / \mathrm{menit})\end{array}$ & $\begin{array}{l}\text { Beban Kerja } \\
(\mathrm{BK})\end{array}$ \\
\hline 1 & 0.788235 & 1 & 3.53 & 2.782471 \\
\hline 2 & 0.745098 & 2 & 3.53 & 2.630196 \\
\hline 3 & 0.686275 & 3 & 2.61 & 1.791176 \\
\hline
\end{tabular}

Dapat dilihat pada tabel 2 - 5 masing - masing butir pertanyaan memiliki nilai RII yang berbeda berdasarkan hasil kuesioner yang sudah diisi oleh para responden yaitu tukang besi di proyek konstruksi.

\section{KESIMPULAN}

Adapun kesimpulan dari hasil analisis dalam penelitian ini yaitu:

1. Berdasarkan hasil perhitungan beban kerja tenaga kerja konstruksi tukang besi maka didapatkan hasil sebagai berikut :

a. Beban Kerja untuk Variabel Beban Fisik sebesar 3.266294 Kkal/menit

b. Beban Kerja untuk Variabel Kemampuan sebesar $3.314078 \mathrm{Kkal} / \mathrm{menit}$ 
c. Beban Kerja untuk Variabel Tingkat Kelelahan sebesar 3.387711 Kkal/menit

d. Beban Kerja untuk Variabel Pengaruh Psikologis sebesar 2.401281 Kkal/menit

2. Dari hasil perhitungan maka diketahui bahwa beban kerja berdasarkan variabel tingkat kelelahan memiliki nilai yang paling besar.

3. Dari hasil yang telah didapat diatas, menunjukan bahwa perhitungan beban kerja dari persepsi tenaga kerja konstruksi di Jakarta dapat dikatakan sebagai pekerjaan yang berat, hal ini memperlihatkan adanya keselarasan dengan hasil dari beberapa penelitian sebelumnya yang menyatakan bahwa pekerjaan sebagai tukang besi diklasifikasikan sebagai pekerjaan yang berat (Abdellhamid dan Everett, 2000,2002).

\section{DAFTAR PUSTAKA}

Abdelhamid, T. S., and Everett, J. G. (2002). Physical demands of construction work: A source of workflow unreliability. Proceedings of the 10th Annual Conference for Lean Construction, Gramado, Brazil, 6-8 August 2002, 75-86

Abdelhamid, T. S., and Everett, J. G. (2000). Ironworkers: Physiological Demands during construction work. Construction Congcress VI

Astrand, P., and Rodahl, K. (1986). Textbook of work physiology, physiological bases of exercise. McGraw-Hill, New York.

Castenada, J. et.al. (2005). “Worker's Skill and Receptiveness to Operate Under The Tier II Strategy Management Strategy”. J. Constr. Eng. Manage., 10.1061/(ASCE)07333-9364(2005)131:7(799), 709-807

Hartmann, B., and Fleischer, A. G. (2005). "Physical load exposure at construction sites.". Scand. J. Work Environ. Health, 31(2), 88-95

Janaro, R. E. (1982). The Development and Implementation of Optimal Multi-Rest Break Scheduling Models. Ph.D. Dissertation, Florida State University, Florida.

Jergeas. G. (2010). Top 10 Areas for Construction Productivity Improvement on Alberta Oil and Gas Construction Project. Cons. Research Project 2010, ASCE, Reston, VA, 1030-1038

Soeharto, Iman. (1997). Manajemen Proyek. Erlangga. Jakarta

Zhang, M.,et.al.. (2015). Influence of Fatigue on Construction Workers' Pysical and Cognitive FunctionI. The Society of Occupational Medicine: Oxford Universtiy Press 